\title{
PROBABLE PROSTATE CANCER IN A PRE-INCAIC INDIVIDUAL FROM PUKARA DE LA CUEVA, NORTHWESTERN ARGENTINA
}

\author{
Leandro Luna*; Claudia Aranda**; Ana Luisa Santos***; Paola Ramundo****; Claudio \\ Rizzuti*****; Diego Stagno*****
}

*CONICET. Ethnographic Museum J. B. Ambrosetti, Faculty of Philosophy and Letters, University of Buenos Aires, Argentina. Moreno 350 (1091), Buenos Aires, Argentina. Email: lunaranda@gmail.com; ** Ethnographic Museum J. B. Ambrosetti, Faculty of Philosophy and Letters, University of Buenos Aires, Argentina; ***Department of Life Sciences and CIAS, University of Coimbra, Portugal; ****CONICET. Ethnographic Museum J. B. Ambrosetti, Faculty of Philosophy and Letters, University of Buenos Aires, Argentina/Archaeological Studies Program, Argentine Catholic University; *****University of Buenos Aires, Argentine Society of Radiology.

Number of illustrations: 10 .

Number of tables: 2.

\begin{abstract}
Prostate carcinoma is a common malignant neoplasia that mostly metastasizes to bone in males. Nonetheless, the number of paleopathological cases reported is very small and only two from South American individuals, almost of them being identified in Europe. The purpose of this paper is to document the lesions identified in a new Pre-Columbian (around 1400 AD) individual that corresponds to a middle-aged male from Pukara de la Cueva, Jujuy province, in the Northwest region of Argentina. The skeleton was found disarticulated but it is nearly complete and well preserved. The overall character of the lesions observed is predominantly proliferative in nature, but osteolytic and mixed patterns were also detected in both axial and appendicular skeleton. Macroscopically, this overall pattern and the distribution of the lesions are compatible with a secondary cancer. Radiological examination showed multiple dense areas with sclerotic borders in several bones, which confirm the previous diagnosis of prostate carcinoma. The exuberance and dissemination of the lesions all over the skeleton led infer individual cachexy implying that he would have been assisted by his family and/or social group during the chronic process. Carcinogenic risk factors are also discussed in order to ascertain the possible causes of the disease. This analysis adds a new evidence of a Pre-Columbian carcinoma in a South American native population and enhances the possibilities of an adequate differential diagnosis.
\end{abstract}

Key words: tumor, metastases, proliferative bone, osteolytic lesions, paleopathology. 


\section{INTRODUCTION}

Prostate cancer is one the most aggressive malignant tumor that metastases in bone, with around 70-90\% of the patients developing osteoblastic and osteolytic lesions in the skeleton (Aufderheide and Rodríguez-Martín, 1998; Coleman, 2001; Ortner, 2003; Keller and Brown, 2004; Resnick and Kransdorf, 2005; Marks and Hamilton, 2007; Waldron, 2009). Even so, there are few cases reported in the paleopathological bibliography. In South America, only two Peruvian skeletons with prostate metastases were identified, one from the Pre-Incaic site of Huaca Las Ventanas, dated 900-1100 AD (Baraybar and Shimada, 1993) and the other from Caleta de San José, dated ca. 1375-1475 AD (Klaus, 2008). In North America, only Ortner (2003) inferred the presence of prostate cancer in a 1500-1600 AD individual from Florida. Schultz and co-authors (2007) claimed to have morphological and biochemically diagnosed the most ancient case of the Old World in Siberia (2700 years old), although de la Rúa et al. (1995) studied an older Neolithic (ca. 5000 years BP) individual from the site of San Juan Ante Portam Latinam, in the Basque Country, using macroscopic, radiographic, microscopic and chemical analyses. Other skeletal evidences of prostate metastases in Europe are a cremated individual from the $1^{\text {st }}$ century AD in Italy (Grevin et al., 1997) and five Medieval cases: one from a cemetery near Dubendorf, Switzerland (Ortner and Putschar, 1981), a skeletal specimen from Homokmégy-Székessite, Hungary (Zink et al., 2004; Molnar et al., 2009), another from Svendborg, Denmark (Tkocz and Bierring, 1984) and two recovered in England, one from Canterbury (Anderson et al., 1992; Wakely et al., 1995) and the other from Wharram Percy (Mays et al., 1996). Finally, there is a more recent case from the $19^{\text {th }}$ century AD London analyzed by Waldron (1997), and an identified skeleton from the Lisbon collection was macroscopically and histologically studied by Assis (2013).

As can be seen from this bibliography survey, evidence of this condition is rare worldwide and not previously reported in the Argentinean territory. The goal of this paper is to analyze a pre-Incaic human skeleton temporally located within the local period known as Período de los Desarrollos Regionales II (PDRII; ca. 1250-1430 AD) that shows osteoblastic, osteolythic and mixed lesions compatible with a metastatic carcinoma of the prostate. The intense bone response consequence of the pathological development was probably responsible of the progressive physical weakness and health deterioration of this individual, interfering with his living conditions and the daily activities of the social group to which he belonged.

\section{THE PUKARA DE LA CUEVA SITE}

The term pukara relates to pre-Hispanic settlements, located in elevated, naturally defended places, usually with difficult access and very good visibility. They were frequently surrounded by a defense wall and included numerous conglomerated dwellings (Madrazo and Ottonello, 1966; Ruiz and Albeck, 1997; Tarragó, 2000). The Pukara de la Cueva is an archaeological site located in La Cueva gorge at Humahuaca district, Jujuy province, Northwestern Argentina. In this area, numerous archaeological sites with chronologies between the Later Formative and Inka Periods (from ca. 900 AD to 1536 AD) were identified (Nielsen, 2001; Ramundo, 2012). Pukara de la Cueva is located 3500 meters above sea level, has approximately 1000 square meters and more than 150 architectural structures along with internal circulation areas, several probable public areas, stockyards and access pathways (Basilico, 1998; Ramundo, 2012). The people who lived in this pukara were mainly potters, agriculturalists and long-distance pastoralists (Ramundo 2012).

In the first archeological surveys that took place in the 1930', primary inhumations of adult individuals in a seated flexed position were found under the floor of three residential units. Casanova (1933) very briefly described these findings, without further laboratory research. Since 1980's, this site has been subject of new investigations (Basílico, 1998). In 2008, a $3 \mathrm{~m} \mathrm{x} 4 \mathrm{~m}$ excavation was done using modern archaeological methodologies and 
commingled human remains were found near the foundations of a pre-Hispanic wall (Fig. 1). During laboratory analyzes a minimal number of 6 individuals was estimated: three nonadults (two infants and one adolescent), two middle adult females and an adult male. During this process, it was observed that a group of bones with the same color, robustness and relative size showed similar massive pathological lesions, indicating that they belonged to the same male individual, called "skeleton number 5" (Aranda et al., 2012). Two radiocarbon dates were obtained from this individual $(540 \pm 60$ and $549 \pm 30$ years BP in an humerus -LP 2268- and a rib -MTC-15600- fragment, respectively; Aranda et al., 2012), placing him just prior to the arrival of the Inca in the area.

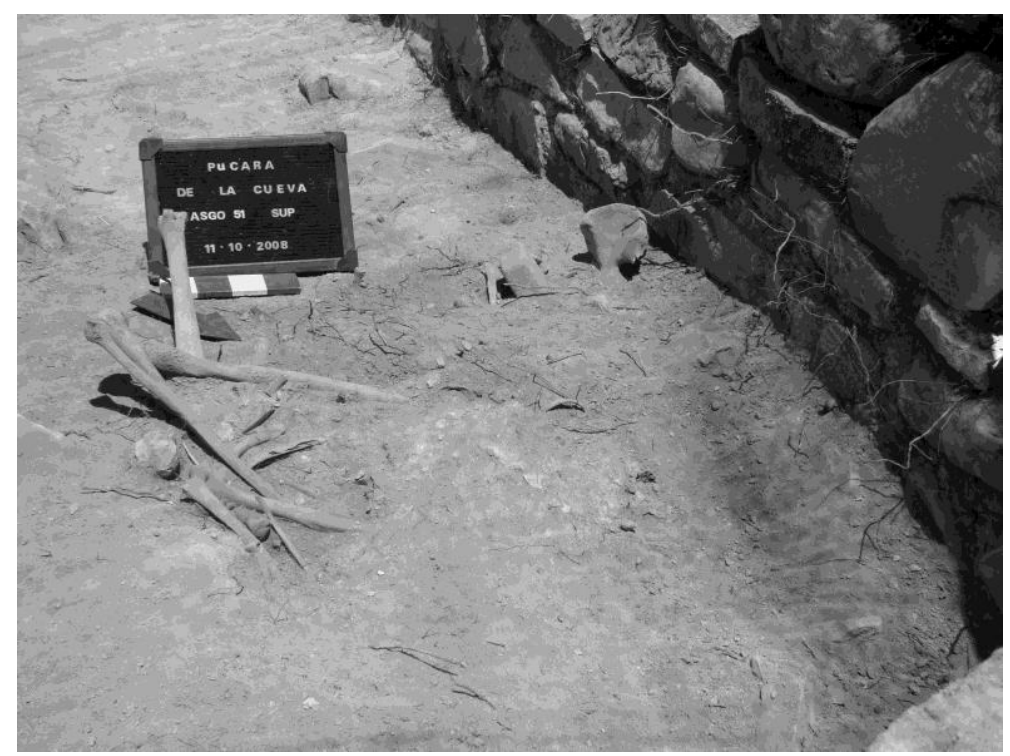

Figure 1. Area of the excavation showing the commingled bones and the Pre-Hispanic wall.

\section{MATERIAL AND METHODS}

The human remains of the 6 individuals were studied and, beside oral pathology, 5 of them didn't show macroscopic evidence of pathologies in their bones (Aranda et al., 2012). The specificity and the rarity of the conditions observed in the adult male (\# 5) forced to the elaboration of a detailed examination, focus of this paper. This individual is a fairly complete skeleton (Fig. 2) with well preserved bones except for the skull which is very fragmented and incomplete. From the postcranial skeleton, only the left patella and several small bones such as those from feet were absent. According to standard methods (Buikstra and Ubelaker, 1994), this skeleton belonged to a middle-aged male (Aranda et al., 2012).

The bones were observed in detail, macroscopically and with a magnified lens. The lesions identified were both proliferative and osteolytic, but a mixed form was also detected. The distinction between woven and lamellar new tissues was stated taking into account the descriptions given by Ortner (2003) and Matos and Santos (2006). In order to observe the general distribution of the lesions, their location was recorded in a skeletal diagram (Fig. 2). After the description of the pathological manifestations sixteen bones, with and without osseous changes, and from different anatomic regions, were selected to radiological exam. Radiographs were taken in Imagen Test facilities with a Toshiba Monocomando Digital equipment, Dinar model, and the images were processed using a Digital Carestream program. 

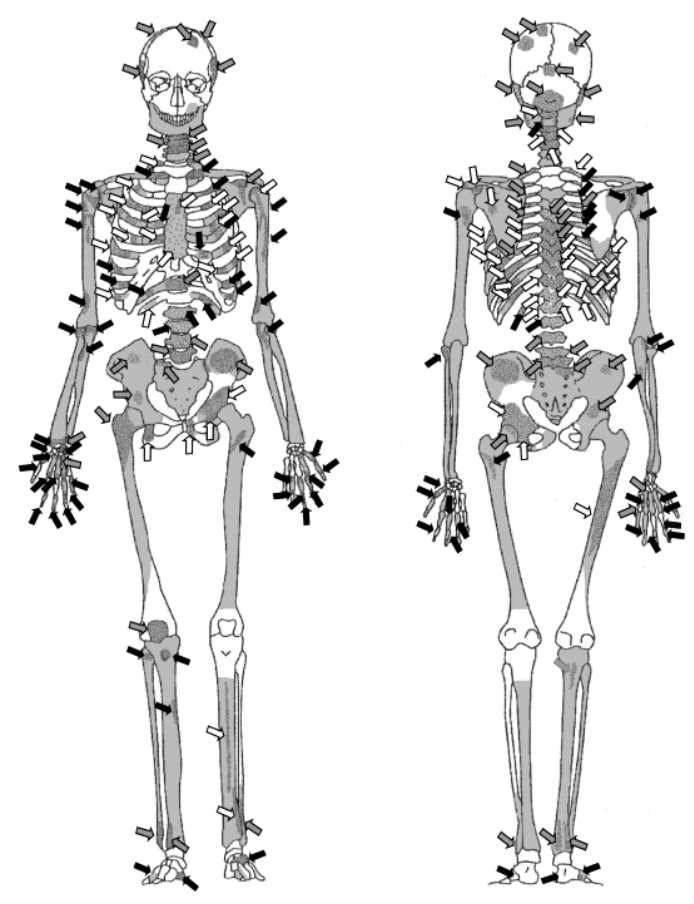

Figure 2. Skeletal sketches with the bones recovered in light grey and the pathological lesions signed in dark grey. Grey arrows point to proliferative lesions, black to osteolytic and white to both types of bone reactions.

\section{RESULTS}

The distribution of the lesions along the skeleton is provided in Table 1 and in Figure 2. Pathological manifestations are bilateral and present all over the skeleton. The intraskeletal distribution shows that only proliferative lesions occur alone in the skull. In the post cranial skeleton both types are present, with predominance of bone growth in the axial area (Fig. 3) and in the pelvis. New bone formation is visible in bones as the scapula (Fig. 4) and ribs (Fig. 5). Osteolytic defects are mostly present in the upper limb and in the distal ends of lower limb bones. The most outstanding lesions were recorded in both os coxae, especially in the left (Fig. 6). Both visceral (Fig. 6A) and posterior (Fig. 6B) surfaces are affected by pathological lesions. The iliac fossa is covered by a layer of new bone, reaching ca. $14 \mathrm{~mm}$ in high, with numerous spiculae perpendicular to the cortical surface (Fig. 6C), while in the posterior views of the ilium alae and in the ilioischial region (Fig. 6D) there are massive outgrowths of highly irregular spiculae. The proximal thirds of the femora show the same trend of bone growth (Fig. 7). The proliferative lesions observed in this skeleton are mainly spiculated, in disorganized (Fig. 5) or organized (Fig. 6C) patterns, although dense undulating periosteal reactions are also seen in areas such as the gonial region of the mandible and several rib epiphyses (Table 2). No laminate appearance is seen in the cortex of any bone.

The radiological examination revealed multifocal and geographic dense areas with sclerotic borders in fragments of the skull, scapula, vertebrae (Fig. 8), coxae (Fig. 9), femora and ribs (Fig. 10). In the radiographs, the ulna (Fig. 10) and the hand phalanges are apparently non-affected, despite the slight osteolytic lesions macroscopically visible in some of the proximal and distal epiphyses (Fig. 2). 


\section{DIFFERENTIAL DIAGNOSIS AND DISCUSSION}

Malignant tumors are a major problem in nowadays societies. There are multiple factors attributable to its high incidence, but to understand the natural history of these conditions it is important to firstly trace their evolutionary pathways. Evidences of these diseases are rare in ancient populations, because paleoncology counts with very few cases as the identification and differential diagnosis are difficult in skeletal derived samples. In general, the most affected bones for any secondary cancer are those of the vertebral column, pelvis girdle, thorax, proximal epiphyses of humerus and femora, in concordance with the main location of the hematopoietic marrow (Thillaud, 1996). The dissemination may occur through the circulatory or lymphatic systems, promoting the proliferation of multiple lesions in the specific areas where lymphatics and arteries enter the bone structure (Marks and Hamilton 2007). Metastatic bone tissues, even in those cases predominantly osteolytic, may show a variable amount of bone reaction (Marques et al., 2011). Thus, the identification of the primary focus should be made mainly done considering the difference between proliferative or erosive nature of the lesions and their location (Ortner, 2003). An exuberant osteoblastic activity with very sclerotic borders and in occasions also with some bone destruction is, according to the specialized literature, mainly a response to prostate cancer in males, although primary tumors in the lung, kidney and thyroid cannot be ruled out (Rosenthal, 1997; Aufderheide and Rodríguez-Martín, 1998; Ostendorf Smith, 2002; Ortner, 2003; Chhem and Brothwell, 2008; Waldron, 2009). Secondary lesions to prostate cancer are more sclerotic and proliferative, while those provoked by lung carcinomas are mainly osteolytic (Schultz et al., 2007; Waldron, 2009). Recent studies had identified that the development of prostate cancer metastases produces osteoblastic new bone depositions associated with osteoclastic activity, both derived from the same whole process (Mundy, 2002; Keller and Brown, 2004). Thus, the case presented in this paper is more likely related to the first type of disease.

In PDR period, direct primary inhumations below the floors of the domestic dwellings were common in Northwestern Argentina (Lafón, 1967; Palma, 1998; Nielsen, 2001, among others) and secondary single or collective burials were also sometimes found (e.g. Nielsen 2001). In this case, despite the fact that the bones of the 6 individuals recovered are commingled and associated with some cultural items, such as decorated and non-decorated ceramic shreds of PDRII, some lithic artifacts, faunal bones, ochre and valve beads (Aranda et al. 2012), there is no evidence of important postmortem osseous deterioration caused by taphonomic agents. Thus, it is impossible to know if the spatial arrangement within the assemblage was a consequence of a cultural practice or due to a posterior sediment removal that affected the bone distribution. Beside this consideration, only the bones corresponding to the male showed the lesions previously described, considered to be the effect of the proliferation of a metastazing carcinoma with a prostatic primary focus.

According to Lastres and Cabieses (1959) malignant tumors, primary or metastatic, where commonly present in Pre-Columbian populations. In the present territory of Argentina, one case of metastatic carcinoma was previously reported, a pre-Hispanic hunter-gatherer middle-aged male from Western Pampas. As it only shows multiple osteoclastic activity in the axial skeleton and proximal epiphyses of femora and humeri, the primary focus could not be precisely identified (Luna et al., 2008). On the contrary, the male individual under analysis in the present paper exhibits striking new bone formations in specific areas of the skeleton, being the first case in which the soft tissue formerly affected was recognized. The concomitance among new bone formation, osseous destruction and mixed lesions, their distribution along the skeleton and the sex and age of the individual, is consistent to a metastatic carcinoma of the prostate (Ortner, 2003; Marks and Hamilton, 2007; Brothwell, 2008). The external contours of some of the affected bones, especially those of the visceral 
area of the pelvic girdle, are much altered as massive new subperiosteal bone is deposited in the form of mossy and dense spiculae. The lesions "typically display a mixture of osteolytic and osteoblastic reactions with sharp, distinct scallop-shaped borders and borders with attendant osteoblastic remodeling" (Marks and Hamilton, 2007: 228-229). Only the pathological signals recorded in fibulae and hand and foot bones are slight and mainly erosive in this case. Although rectal cancer tends to produce a rather similar pattern of strong new bone deposition, the overall distribution, the extreme and almost exclusively osteoblastic activity of the metastases and the compactness of the resulting secondary tissue usually deposited in the axial, pelvic and thoracic areas (Rosenthal 1997; Resnick and Kransdorf 2005; Assis 2013), is dissimilar enough to discard it as a primary focus of the neoplastic disease.

A spicular periosteal reaction is usually observed in rapid and aggressive conditions such as malignant tumors (Ortner, 2003; Assis, 2013) and has been categorized in three different subtypes depending on the size and orientation of the spiculae: hair-on-end and sunburst pattern, velvet, and disorganized (Wenaden et al., 2005; Rana et al., 2009; Assis, 2013). According to these authors, the hair-on-end pattern is characterized by parallel bone spiculae perpendicularly projected from the cortex of the bone, as the lesions present at the os coxae. The spiculae tend to be long and thin in the focus of the pathological activity, decreasing in height in the surroundings. In the sunburst appearance the proliferation of new bone shows radial outgrowths starting from a clear center point, and spiculae don't have the perpendicular orientation characteristic from hair-on-end. This is visible in the rib diaphyses (Fig. 5) and in the acetabular and pillar area of the coxae. The velvet reaction shows short and local oblique spiculae with a smooth appearance. This manifestation is present in several areas of the skeleton, such as in the mandible, the ribs, the scapulae and the ilia. The fourth subtype seen in this case, defined by disorganized spiculae leading to a non-patterned appearance, is present in elements from all the anatomic portions (see Table 2).

Bone response to disease is limited to formation or destruction and abnormalities in size, shape and density (Ortner, 2003). That's why many diagnoses of secondary tumors need radiological examination in paleopathological studies to adequately precise the primary focus of the malignancy (Brothwell, 2012). This was not mandatory in the case under analysis since the lesions were macroscopically evident; however, the radiographs clearly showed the dispersion and characteristics of the lesions in the inner structure of the bone, giving much more strength to the differential diagnosis. The massive replacement of the spongy cells of the marrow substance by dense new formed bone, inferred in the radiopaque radiograph signals, must have provoked chronic anemia during the final phase of the life of this man (see Schultz et al., 2007). Moreover, other systemic symptomatology suffered should have been bone pain, progressive physical weakness, impaired mobility and finally the systemic collapse (Keller and Brown, 2004). This process should have caused an incremental impairment related to the final phase of the disease (Dettwyler, 1991; Hawkey, 1998) and a consequently almost full assistance of some of his relatives or other members of the social group.

Direct aetiology of neoplasias is still not completely known and multificatorial (Brothwell, 2008). Risk factors are diverse and include genetic, epigenetic, demographic and environmental (mainly occupation and nutrition) aspects (Brothwell, 1967; Aufderheide and Rodríguez-Martín, 1998; Krtolica et al., 2001; Hsing and Chokkalingam, 2006; Masoro, 2006; Waldron, 2009). According to Hsing and Chokkalingam (2006: 1388), "as much as $42 \%$ of the risk of prostate cancer may be accounted for by genetic influences", although dietary habits and lifestyle factors are also two of the main contributors of the occurrence of clinical prostate cancer (see e.g. Shen and Abate-Shen, 2010). Isotopes values obtained for this individual $\left(\delta^{13} \mathrm{C}=-20.2 \%\right.$ ) indicate a very low maize consumption and a diet based on C3 vegetables and herbivore animals (Aranda et al., 2012), so that diet seems not to have been 
a fundamental contributor in the development of the disease. Some authors also refer that endogamous groups are more susceptible to this diseases through mutation transmission due to small population size (v.g. Halperin, 2004). This is potentially the case of the societies in which the individual under study came from, because during the Pre-Incaic period, a process of endemic war was raised in the Humahuaca gorge area (Nielsen 2007). As the Pukara de la Cueva is the Northern strategically entrance to the gorge, we propose that different social changes may have occurred, mainly a higher population density inside the Pukara, the development of an overcrowded community and a diminution of the previous social interaction with neighbor societies. This process would have promoted more intense intermarriage linkages among the inhabitants of the Pukara, enhancing the chances of deleterious gene transmissions.

In general, tumors are very scarcely documented in paleopathological literature. One of the most common statements used to explain the low prevalence of metastatic cancer in ancient times is related to the supposed short life expectancy (i.e. Brothwell, 1967, 2012; Wakely et al. 1995; Aufderheide and Rodríguez-Martín, 1998; Ortner, 2003; Marks and Hamilton, 2007; Waldron, 2009; Shen and Abate-Chen, 2010; Prates et al., 2011). This proposal is especially important in this case because prostate cancer is more likely to affect men older than sixty (Waldron, 2009). Clinical research points that the single most significant risk factor for prostate cancer is advanced age and senescence. While men younger than 40 years old have a 1/10.000 chance of developing prostate cancer, this risk increases to $1 / 7$ by the age of 60 (American Cancer Society 2009 in Shen and Abate-Chen, 2010). Nevertheless, studies in documented skeletal samples show that there are no accurate methods for age estimation, especially for elderly individuals, and that the current approaches tend to underestimate middle and older adult ages (Martins et al., 2012). Another important reason usually quoted for the explanation of the low prevalence of cancer in antiquity is the absence of many of the nowadays carcinogens developed mainly after the Industrial Revolution (Prates et al., 2011). However, in sedentary preindustrial societies, environmental pollution derived from the increase of population densities, the enhancing overcrowding and the less hygienic lifestyle could have had an important role in promoting the proliferation of malignant primary cells. This scenario would have been possible in Pukara de la Cueva since the beginning of a probable endemic warfare process must have derived in this settlement and sociocultural pattern.

Malignant neoplasias usually derive in a lethal condition. However, the macroscopic and radiographic lesions are so striking that led to wonder about the survival of this individual, following the statements previously put by authors like Ortner (1991) and Wood et al. (1992): was he able to survive for a long period with the disease that the skeleton could report the changes provoked by the uncontrolled bone growth, or his immune system was so weak that the bones were strongly affected in a short period of time? As prostate cancer could remain silent due to its slow and non-symptomatic development, sometimes during years (Keller and Brown 2004), the first hypothesis seems to be more likely in this case.

\section{CONCLUSION}

The scarcity of studies about neoplastic pathologies in ancient societies shows the need to make efforts to understand in depth the incidence of such diseases in the past. The paleopathological analysis of this skeleton allowed identifying the development of a metastatic prostate cancer in pre-Hispanic societies. This evidence is especially important because it is one of the first cases analyzed in detail in South America and the first of its kind in Argentina. The finding contributes to the discussion of the environmental and behavioral characteristics where these populations lived, which gave rise to the development of this very unusual disease before industrialization. It is possible to suggest that the basic socio- 
environmental conditions (hygienic, demographic, climatic and/or genetic) were given for the appearance of malignant prostate cells, their proliferation and subsequent spread to the skeletal system. The detailed macroscopic and radiographic analyses allowed identifying osteoblastic, osteoclastic and mixed pathological manifestations, contributing to the differential diagnosis of the disease and to the characterization, in dry bones, of patterns systematically observed in clinical cases. This contributes to the understanding of neoplastic manifestations in the past and helps to outline a history of the disease, a significant fact for the full characterization of the variability of the processes of proliferation of malignant cells in the present.

\section{ACKNOWLEDGMENTS}

We would like to thanks to the archeological team involve in the excavation and in the laboratory. Thanks are also due to the Laboratory of Bone Chemistry and Prehistory from University of Tokio, Japan and to Klaus Haagen and Guido Lombardi.

\section{LITERATURE CITED}

Anderson, T., Wakely, J. \& Carter, A. (1992): Medieval example of metastatic carcinoma: a dry bone, radiological, and SEM study. - Am. J. Phys. Anthropol. 89, 309-323.

Aranda, C., Luna, L. \& Ramundo, P. (2012): Primeros análisis y conservación preventiva del registro bioarqueológico del Pukara de la Cueva (Humahuaca, Jujuy). - Rev. Argent. Antropol. Biol. 14, 9-21.

Assis, S. (2013): Beyond the Visible World: Bridging Macroscopic and Paleohistopathological Techniques in the Study of Periosteal New Bone Formation in Human Skeletal Remains. - Ph.D. dissertation, University of Coimbra, Coimbra. Aufderheide, A. \& Rodríguez-Martín, C. (1998): The Cambridge Encyclopaedia of Human Paleopathology. - Cambridge University Press, Cambridge.

Baraybar, J. \& Shimada, I. (1993): A possible case of metastatic carcinoma in a Middle Sicán burial from Batán Grande, Peru. - Int. J. Osteoarchaeol. 3,129-135. Basílico, S. (1998): Relevamiento planimétrico del Pucara de La Cueva (Humahuaca, Jujuy). - In: Cremonte, B. (ed.): Los Desarrollos Locales y sus Territorios. - Universidad Nacional de Jujuy, Jujuy, pp. 245-255.

Brothwell, D. (1967): The evidence of neoplasms. - In: Brothwell, D. \& Sandison, A. (eds.): Diseases in Antiquity: a Survey of the Diseases, Injuries and Surgery of Early Populations. Charles C. Thomas, Springfield, pp. 320-345.

Brothwell, D. (2008): Tumours and tumour-like processes. - In: Pinhasi, R. \& Mays, S. (eds.): Advances in Human Palaeopathology. - Wiley-Blackwell Publishing Ltd., Chichester, pp. 253-284.

Brothwell, D. (2012): Tumors: problems of differential diagnosis in paleopathology. - In: Grauer, A. (ed.): A Companion of Paleopathology. -Wiley-Blackwell Publishing Ltd., Chichester, pp. 420-433.

Buikstra, J., \& Ubelaker, D. (1994): Standards for Data Collection from Human Skeletal Remains: Proceedings of a Seminar at the Field Museum of Natural History. - Arkansas Archaeological Survey Research Series No. 44, Arkansas.

Casanova, E. (1933): Tres ruinas indígenas en la quebrada de La Cueva. - Anales del Museo Nacional de Historia Natural Bernardino Rivadavia 37, 255-319.

Chhem, R. \& Brothwell, D. (2008): Paleoradiology: Imaging Mummies and Fossils. Springer-Verlag, Berlin.

Coleman, R. (2001): Metastatic bone disease: clinical features, pathophysiology and treatment strategies. - Cancer Treat. Rev. 27, 165-176. 
de la Rúa, C., Baraybar, J. \& Etxeberria, F. (1995): Neolithic case of metastasizing carcinoma: multiple approaches to differential diagnosis. - Int. J. Osteoarchaeol. 5, 254-264. Dettwyler, K. (1991): Can paleopathology provide evidence for "compassion"? - Am. J. Phys. Anthropol. 84, 375-384.

Grévin, G., Lagier, R. \& Baud, C. (1997): Metastatic carcinoma of presumed prostatic origin in cremated bones from the first century AD. - Virchows Arch. 431, 211-214. Halperin, E. (2004): Paleo-oncology: the role of ancient remains in the study of cancer. Perspect. Biol. Med. 47(1), 1-14. Hawkey, D. (1998): Disability, compassion and the skeletal record: using musculoskeletal stress markers (MSM) to construct an osteobiography from Early New Mexico. - Int. J. Osteoarchaeol. 78, 326-340.

Hsing, A. \& Chokkalingam, A. (2006): Prostate cancer epidemiology. - Front. Biosci. 11, $1388-1413$.

Keller, E. \& Brown, J. (2004): Cancer bone metastases promote both osteolytic and osteoblastic activity. - Journal of Cellular Biochemistry 91, 718-729.

Klaus, H. (2008): Out of Light Came Darkness: Bioarchaeology of Mortuary Ritual, Health, and Ethnogenesis in the Lambayeque Valley Complex, North Coast of Peru (AD 900-1750). $\mathrm{Ph} . \mathrm{D}$. dissertation. Ohio State University, Columbus.

Krtolica, A., Parrinello, S., Lockett, S., Despres, P. \& Campisi, J. (2001): Senescent fibroblasts promote epithelial cell growth and tumorigenesis: a link between cancer and aging. - P. Natl. Aca. Sci. USA 98, 12072-12077.

Lafon, C. (1967): Un estudio sobre la funebria Humahuaca. - Runa X, 195-255. Lastres, J. \& Cabieses, F. (1959): La trepanación del cráneo en el antiguo Perú. - An. Fac. Med. 42, 258-320.

Luna, L., Aranda C., Bosio L. \& Berón M. (2008): A case of multiple metastasis in Late Holocene hunter-gatherers from the Argentine Pampean Region. - Int. J. Osteoarchaeol. 18, 492-506.

Madrazo, G. \&Ottonello, M. (1966): Tipos de Instalación Prehispánica en la Región de la Puna y su Borde. - Monografías N ${ }^{\circ}$. Museo "D. Arce", Olavarría, Buenos Aires, Argentina. Marks, M. \& Hamilton, M. (2007): Metastatic carcinoma: palaeopathology and differential diagnosis. - Int. J. Osteoarchaeol. 17, 217-234.

Marques, C., Santos, A. \& Cunha, E. (2013): Better a broader diagnosis than a misdiagnosis: the study of a neoplastic condition in a male individual who died in early 20th century (Coimbra, Portugal). - Int. J. Osteoarchaeol. 23, 664-675.

Martins, R., Oliveira, P. \& Schmitt, A. (2012): Estimation of age at death from the pubic symphysis and the auricular surface of the ilium using a smoothing procedure. - For. Sci. Int. 219(1), 287.e1-287.e7.

Masoro, E. (2006): Are age-associated diseases an integral part of aging? - In: Masoro, E. \& Austad, S. (eds): Handbook of the Biology of Aging. - Academic Press, San Diego, pp. 43-62. Matos, V. \& Santos, A. L. (2006): On the trail of pulmonary tuberculosis based on rib lesions: Results from the human identified skeletal collection from the Museu Bocage (Lisbon, Portugal). - Am. J. Phys. Anthropol. 130, 190-200.

Mays, S., Strouhal, E., Vyhnánek, L. \& Nêmecková, A. (1996): A case of metastatic carcinoma of medieval date from Wharram Percy, England. - J. Paleopathol. 8, 33-42. Molnár, E., Marcsik, A., Bereczki, Z., Schmidt-Schultz, T., Schultz, M. \& Pálfi, G. (2009): Malignant tumors in osteoarchaeological samples from Hungary. - Acta Biol. Szegediensis 53, 117-124. Mundy, G. (2002): Metastasis to bone: causes, consequences and therapeutic opportunities. Cancer 2, 584-593. 
Nielsen, A. (2001): Evolución social en la quebrada de Humahuaca (AD 700-1536). - In: Berberián, E. \& Nielsen, A. (eds.): Historia Argentina Prehispánica. - Brujas, Córdoba, pp. 190-197.

Nielsen, A. (2007): Celebrando con los Antepasados. Arqueología del Espacio Público en Los Amarillos, Quebrada de Humahuaca, Jujuy, Argentina. - Buenos Aires, Mallku. Ortner, D. (1991): Theoretical and methodological issues in paleopathology. - In: Ortner, D. \& Aufderheide, A. (eds.): Human Paleopathology: Current Syntheses and Future Options. Washington, DC, Smithsonian Institution Press, pp. 5-11. Ortner, D. (2003): Identification of Pathological Conditions in Human Skeletal Remains. London, Academic Press.

Ortner, D. \& Putschar, W. (1981): Identification of Pathological Conditions in Human Skeletal Remains. Smithsonian Contributions to Anthropology, 28. - Washington D.C., Smithsonian Institution Press.

Ostendorf Smith, M. (2002): A probable case of metastasic carcinoma from the late prehistoric eastern Tennessee River Valley. - Int. J. Osteoarchaeol. 12, 235-247.

Palma, J. (1998): Curacas y señores. Una Visión de la Sociedad Política Prehispánica en la Quebrada de Humahuaca. - Jujuy: Instituto Interdisciplinario Tilcara, Facultad de Filosofía y Letras, Universidad de Buenos Aires.

Prates, C., Sousa, S., Oliveira, C. \& Ikram, S. (2011): Prostate metastatic bone cancer in an Egyptian Ptolemaic mummy, a proposed radiological diagnosis. - Int. J. Paleopathol. 1(2), 98103.

Ramundo, P. (2012): Quebrada de La Cueva (Humahuaca, Jujuy): cronología, espacialidad y cerámica arqueológica. - Relaciones de la Sociedad Argentina de Antropología XXXVII(2), 329-354.

Rana, R. Wu, J. \& Eisenberg, R. (2009): Periosteal reaction. - Am. J. Roentgenol. 193(4), w259-w272.

Resnick, D. \& Kransdorf, M. (2005): Skeletal Metastases. - In: Resnick, D. \& Kransdorf, M. (eds.): Bone and Joint Imaging. - Philadelphia, Elsevier, pp. 1245-1264.

Rosenthal, D. (1997): Radiologic diagnosis of bone metastases. - Cancer 80(8), 1595-1607. Ruiz, M. \& Albeck, M. (1997): El fenómeno pukara visto desde la puna jujeña. - Estudios Atacameños 12, 83-95.

Schultz, M., Parzinger, H., Posdnjakov, D., Chikisheva, T. \& Schmidt-Schultz, T. (2007): Oldest known case of metastasizing prostate carcinoma diagnosed in the skeleton of a 2.700 years-old Scythian king from Arzhan (Siberia, Russia). - Int. J. Cancer 121, 2591-2595. Shen, M. \& Abate-Shen, C. (2010): Molecular genetics of prostate cancer: new prospects for old challenges. Genes and Development - 24, 1967-2000.

Tarragó, M. (2000): Chacras y pukara. Desarrollos sociales tardíos. - In: Tarragó, M. (ed.): Nueva Historia Argentina 1. - Buenos Aires, Editorial Sudamericana, pp. 257-300. Thillaud, P. (1996): Paléopathologie Humaine. Paris, Kronos BY. Tkocz, I. \& Bierring, F. (1984): A medieval case of metastasizing carcinoma with multiple osteosclerotic bone lesions. - Am. J. Phys. Anthropol. 65, 373-380.

Wakely, J., Anderson, T. \& Carter, A. (1995): A multidisciplinarian case study of prostatic (?) carcinoma from Mediaeval Canterbury. - J. Archaeol. Sci. 22, 469-477.

Waldron, T. (1997): A nineteenth-century case of carcinoma of the prostate, with a note on the early history of the disease. - Int. J. Osteoarchaeol. 7, 241-247.

Waldron, T. (2009): Palaeopathology. - Cambridge, Cambridge University Press.

Wenaden, A., Szyszko, T. \& Saifuddin, A. (2005): Imaging of periosteal reactions associated with focal lesions of bone. - Clin. Radiol. 60(4), 439-456.

Wood, J., Milner, G., Harpending, H. \& Weiss, K. (1992): The osteological paradox. - Curr. Anthropol. 33, 343-370. 

metastatic cancer from the 10th-11th century in Hungary. $15^{\text {th }}$ European Meeting of the 490 Paloepathology Association: 106. Durham. 


\section{List of tables}

Table 1. Location and type (proliferative, osteolytic or mixed) of the lesions identified. Table 2. Type of spiculated and solid proliferative periosteal lesions for each location.

\section{List of illustrations}

Figure 3. Anterior view of a cervical vertebra of individual 5 with both proliferative and osteolytic bone.

Figure 4. Left scapula A. Proliferative bone in the scapular neck; B. Osteolytic lesion on the anterior surface.

Figure 5. Anterior view of a rib diaphysis with radial and disorganized spiculae. Figure 6. Left os coxae. A. Medial view of the ilium with a layer of massive hair-on-end new bone. B. Lateral view of the ilium covered with both proliferative and osteolytic lesions. C. Fragment of ilium showing linear bone growth ranging from 7 to $14 \mathrm{~mm}$. D. Posterior view of ilioischial fragment presenting nodular and irregular outgrowth of bone.

Figure 7. Right femur. A. In the anterior intertrochanteric area a roughened irregular bone growth is visible. B. Lateral view of the greater trochanter and the proximal epiphysis with nodules of remodeled new bone.

Figure 8. Radiograph of axis, cervical and thoracic vertebrae demonstrating multifocal lesions with sclerotic and irregular borders.

Figure 9. Radiograph of the right ilium with multifocal lesions in the iliac crest and iliac fossa, and radiopacity in the iliopubic area due to the massive proliferation of new bone. Figure 10. Radiological images of the right femur showing sclerotic lesions in the head and in the greater trochanter, and postmortem bone destruction of the diaphysis. Similar lesions are present in a rib shaft fragment while the ulna seems not affected by the neoplastic process. 
Table 1. Location and type (proliferative, osteolytic or mixed) of the lesions identified.

\begin{tabular}{|c|c|c|c|c|c|}
\hline \multirow[b]{2}{*}{$\begin{array}{l}\text { Anatomic } \\
\text { portion }\end{array}$} & \multirow[b]{2}{*}{ Bone } & \multirow[b]{2}{*}{ Area } & \multicolumn{3}{|c|}{ Type of bone } \\
\hline & & & $\begin{array}{l}\text { Proliferative } \\
(\mathrm{P})\end{array}$ & $\begin{array}{l}\text { Osteolytic } \\
(\mathrm{O})\end{array}$ & $\begin{array}{l}\text { Mixed } \\
(\mathrm{P}+\mathrm{O})\end{array}$ \\
\hline \multirow{4}{*}{ Skull } & Temporals & $\begin{array}{l}\text { Around the external } \\
\text { auditory meatus }\end{array}$ & $\mathrm{x}$ & - & - \\
\hline & Occipital & \multirow{2}{*}{ Inner and outer tables } & $\mathrm{x}$ & - & - \\
\hline & Parietals & & $\mathrm{x}$ & - & - \\
\hline & Mandible & $\begin{array}{l}\text { Gonial region, medial } \\
\text { and external surfaces }\end{array}$ & $\mathrm{x}$ & - & - \\
\hline- & Hyoid & $\begin{array}{l}\text { Anterior and posterior } \\
\text { body }\end{array}$ & - & $\mathrm{x}$ & - \\
\hline \multirow{8}{*}{ Thorax } & \multirow{2}{*}{ Sternum } & Manubrium & $\mathrm{x}$ & - & - \\
\hline & & Corpus sterni & - & $\mathrm{x}$ & - \\
\hline & \multirow{2}{*}{$1^{\text {st }} \mathrm{rib}$} & Costal tubercle & - & - & $\mathrm{x}$ \\
\hline & & Distal end & $\mathrm{x}$ & - & - \\
\hline & \multirow{3}{*}{$2^{\text {nd }}-11^{\text {th }}$ ribs } & Vertebral end & $\mathrm{x}$ & - & $\mathrm{X}$ \\
\hline & & Diaphyses & $\mathrm{x}$ & $\mathrm{x}$ & - \\
\hline & & Sternal end & - & $\mathrm{x}$ & - \\
\hline & $12^{\text {th }}$ left rib & $\begin{array}{c}\text { Diaphysis, anterior } \\
\text { surface }\end{array}$ & - & $\mathrm{x}$ & - \\
\hline \multirow{5}{*}{$\begin{array}{l}\text { Vertebral } \\
\text { column }\end{array}$} & Atlas & All bone & - & $\mathrm{x}$ & - \\
\hline & Axis & Body & - & - & $\mathrm{x}$ \\
\hline & $\begin{array}{l}3^{\text {rd }}-7^{\text {th }} \\
\text { cervical }\end{array}$ & \multirow{3}{*}{ All bone } & - & $\mathrm{x}$ & $\mathrm{x}$ \\
\hline & Dorsal & & $\mathrm{x}$ & $\mathrm{x}$ & $\mathrm{x}$ \\
\hline & Lumbar & & $\mathrm{x}$ & $\mathrm{x}$ & - \\
\hline \multirow{4}{*}{$\begin{array}{l}\text { Scapular } \\
\text { girdle }\end{array}$} & Clavicles & Proximal epiphysis & - & $\mathrm{x}$ & - \\
\hline & \multirow{3}{*}{ Scapulae } & $\begin{array}{l}\text { Acromion and coracoid } \\
\text { process }\end{array}$ & - & $\mathrm{x}$ & - \\
\hline & & Posterior scapular neck & $\mathrm{x}$ & $\mathrm{x}$ & - \\
\hline & & Body & $\mathrm{x}$ & - & - \\
\hline \multirow{6}{*}{ Upper limb } & \multirow[b]{2}{*}{ Ulnae } & Proximal epiphysis & - & $\mathrm{x}$ & - \\
\hline & & $\begin{array}{c}\text { Diaphysis and distal } \\
\text { epiphysis }\end{array}$ & $\mathrm{x}$ & - & - \\
\hline & Radius & Both epiphyses & $\mathrm{x}$ & $\mathrm{x}$ & - \\
\hline & Carpals & All bones & $\mathrm{x}$ & $\mathrm{x}$ & - \\
\hline & Metacarpals & \multirow[b]{2}{*}{ Both epiphyses } & $\mathrm{x}$ & $\mathrm{x}$ & - \\
\hline & $\begin{array}{c}\text { Hand } \\
\text { phalanges }\end{array}$ & & - & $\mathrm{x}$ & - \\
\hline \multirow{4}{*}{ Pelvic girdle } & \multirow{4}{*}{ Coxae } & $\begin{array}{c}\text { Anterior and posterior } \\
\text { acetabular area }\end{array}$ & $\mathrm{x}$ & $\mathrm{x}$ & $\mathrm{x}$ \\
\hline & & $\begin{array}{c}\text { Anterior surface of } \\
\text { obturator foramen area }\end{array}$ & $\mathrm{x}$ & - & - \\
\hline & & $\begin{array}{l}\text { Anterior view near the } \\
\text { auricular surface }\end{array}$ & $\mathrm{x}$ & $\mathrm{X}$ & - \\
\hline & & $\begin{array}{l}\text { Anterior view of greater } \\
\text { sciatic notch }\end{array}$ & $\mathrm{x}$ & - & - \\
\hline
\end{tabular}




\begin{tabular}{|c|c|c|c|c|c|}
\hline & & Posterior iliac pillar & $\mathrm{x}$ & - & - \\
\hline & & Left iliac crest & $\mathrm{x}$ & - & - \\
\hline & & Left pubis (anterior) & - & $\mathrm{x}$ & - \\
\hline & & Left pubis (posterior) & $\mathrm{x}$ & - & - \\
\hline & Sacrum & Left wing & - & - & $\mathrm{x}$ \\
\hline \multirow{7}{*}{ Lower limb } & Femora & Proximal half & $\mathrm{x}$ & $\mathrm{x}$ & - \\
\hline & Right patella & Anterior surface & $\mathrm{x}$ & - & - \\
\hline & Tibiae & All bones & $\mathrm{x}$ & $\mathrm{x}$ & $\mathrm{x}$ \\
\hline & \multirow{2}{*}{ Fibulae } & Proximal epiphysis & - & $\mathrm{x}$ & - \\
\hline & & Distal epiphysis & $\mathrm{x}$ & - & - \\
\hline & Tarsal & All bones & - & $\mathrm{x}$ & - \\
\hline & $\begin{array}{c}\text { Foot } \\
\text { phalanges }\end{array}$ & Both epiphyses & - & $\mathrm{x}$ & - \\
\hline
\end{tabular}


Table 2. Type of spiculated and solid proliferative periosteal lesions for each location.

\begin{tabular}{|c|c|c|c|c|c|c|c|}
\hline \multirow{2}{*}{$\begin{array}{l}\text { Anatomic } \\
\text { portion }\end{array}$} & \multirow{2}{*}{ Bone } & \multirow{2}{*}{ Area } & \multicolumn{4}{|c|}{ Type of spiculated periosteal reactions } & \multirow{2}{*}{$\begin{array}{l}\text { Dense } \\
\text { reaction }\end{array}$} \\
\hline & & & Hair-on-end & Sunburst & Velvet & Disorganized & \\
\hline \multirow{4}{*}{ Skull } & Temporals & $\begin{array}{c}\text { Around the external } \\
\text { auditory meatus }\end{array}$ & - & - & - & $\mathrm{x}$ & - \\
\hline & Occipital & \multirow{2}{*}{ Inner and outer tables } & - & - & - & $\mathrm{x}$ & - \\
\hline & Parietals & & - & - & - & $\mathrm{X}$ & - \\
\hline & Mandible & $\begin{array}{c}\text { Gonial region, medial and } \\
\text { external surfaces }\end{array}$ & - & - & $\mathrm{x}$ & - & $\mathrm{x}$ \\
\hline \multirow{8}{*}{ Thorax } & Sternum & Manubrium & - & - & - & $\mathrm{x}$ & - \\
\hline & \multirow{2}{*}{$1^{\text {st }} \mathrm{rib}$} & Costal tubercle & - & - & $\mathrm{x}$ & & $\mathrm{X}$ \\
\hline & & Distal end & - & - & - & $\mathrm{x}$ & $\mathrm{X}$ \\
\hline & \multirow{2}{*}{$2^{\text {nd }}-11^{\text {th }}$ ribs } & Vertebral end & - & - & $\mathrm{X}$ & $\mathrm{X}$ & $\mathrm{X}$ \\
\hline & & Diaphyses & - & $\mathrm{X}$ & $\mathrm{X}$ & $\mathrm{x}$ & - \\
\hline & Axis & Body & - & - & - & $\mathrm{x}$ & - \\
\hline & Dorsals & \multirow{2}{*}{ All the element } & - & - & - & - & $\mathrm{X}$ \\
\hline & Lumbars & & - & - & - & - & $\mathrm{x}$ \\
\hline \multirow{6}{*}{$\begin{array}{l}\text { Scapular } \\
\text { girdle }\end{array}$} & \multirow{2}{*}{ Scapulae } & Acetabulum & - & - & $\mathrm{x}$ & $\mathrm{x}$ & - \\
\hline & & Body & - & - & - & $\mathrm{X}$ & - \\
\hline & Ulnae & Diaphysis and distal epiphysis & - & - & - & $\mathrm{X}$ & - \\
\hline & Radius & Both epiphysis & - & - & - & $\mathrm{X}$ & - \\
\hline & Carpals & All the element & - & - & - & $\mathrm{x}$ & - \\
\hline & Metacarpals & Both epiphysis & - & - & - & $\mathrm{X}$ & - \\
\hline \multirow{4}{*}{ Pelvic girdle } & \multirow{4}{*}{ Coxae } & $\begin{array}{c}\text { Anterior and posterior } \\
\text { acetabular area }\end{array}$ & - & $\mathrm{X}$ & $\mathrm{X}$ & $\mathrm{X}$ & $X$ \\
\hline & & $\begin{array}{c}\text { Anterior surface of obturator } \\
\text { foramen area }\end{array}$ & - & - & $\mathrm{X}$ & $\mathrm{X}$ & - \\
\hline & & $\begin{array}{c}\text { Anterior surface near auricular } \\
\text { surface }\end{array}$ & $\mathrm{X}$ & - & $\mathrm{X}$ & $\mathrm{X}$ & - \\
\hline & & Anterior surface of greater & $\mathrm{x}$ & - & $\mathrm{X}$ & $\mathrm{X}$ & $\mathrm{X}$ \\
\hline
\end{tabular}




\begin{tabular}{|c|c|c|c|c|c|c|c|}
\hline & & sciatic notch & & & & & \\
\hline & & Posterior iliac pillar & - & $\mathrm{x}$ & $\mathrm{x}$ & $\mathrm{x}$ & $\mathrm{x}$ \\
\hline & & Left iliac crest & - & - & $\mathrm{x}$ & $\mathrm{x}$ & $\mathrm{x}$ \\
\hline & & Left pubis (posterior) & - & - & - & $\mathrm{x}$ & - \\
\hline & Sacrum & Anterior left upper wing & - & - & - & $\mathrm{x}$ & - \\
\hline \multirow{4}{*}{ Lower limb } & Femora & Proximal half & - & - & - & $\mathrm{x}$ & $\mathrm{x}$ \\
\hline & Right patella & Anterior face & - & - & - & $\mathrm{x}$ & - \\
\hline & Tibiae & All the element & - & - & - & $\mathrm{x}$ & - \\
\hline & Fibula & Distal end & - & - & - & $\mathrm{x}$ & - \\
\hline
\end{tabular}




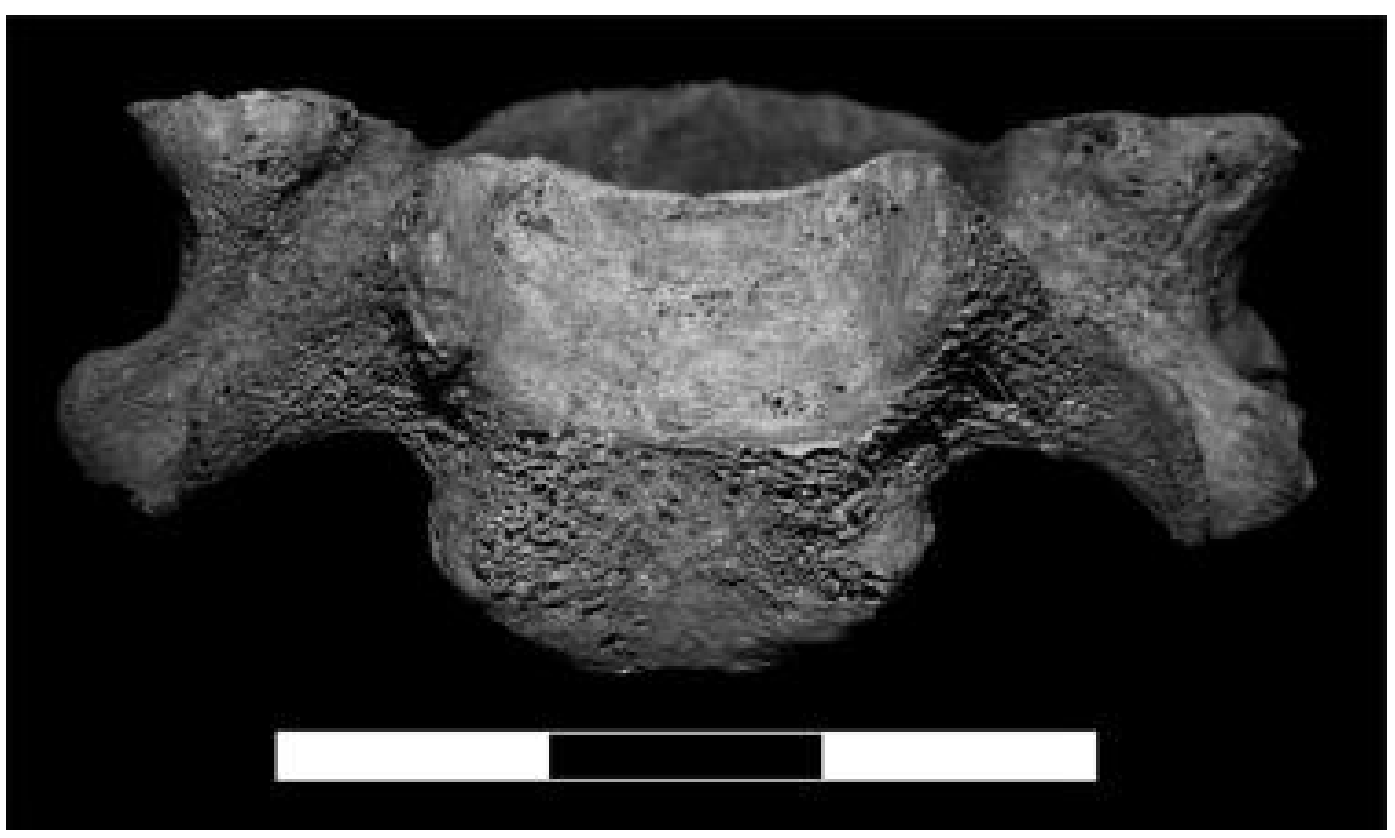

Figure 3.

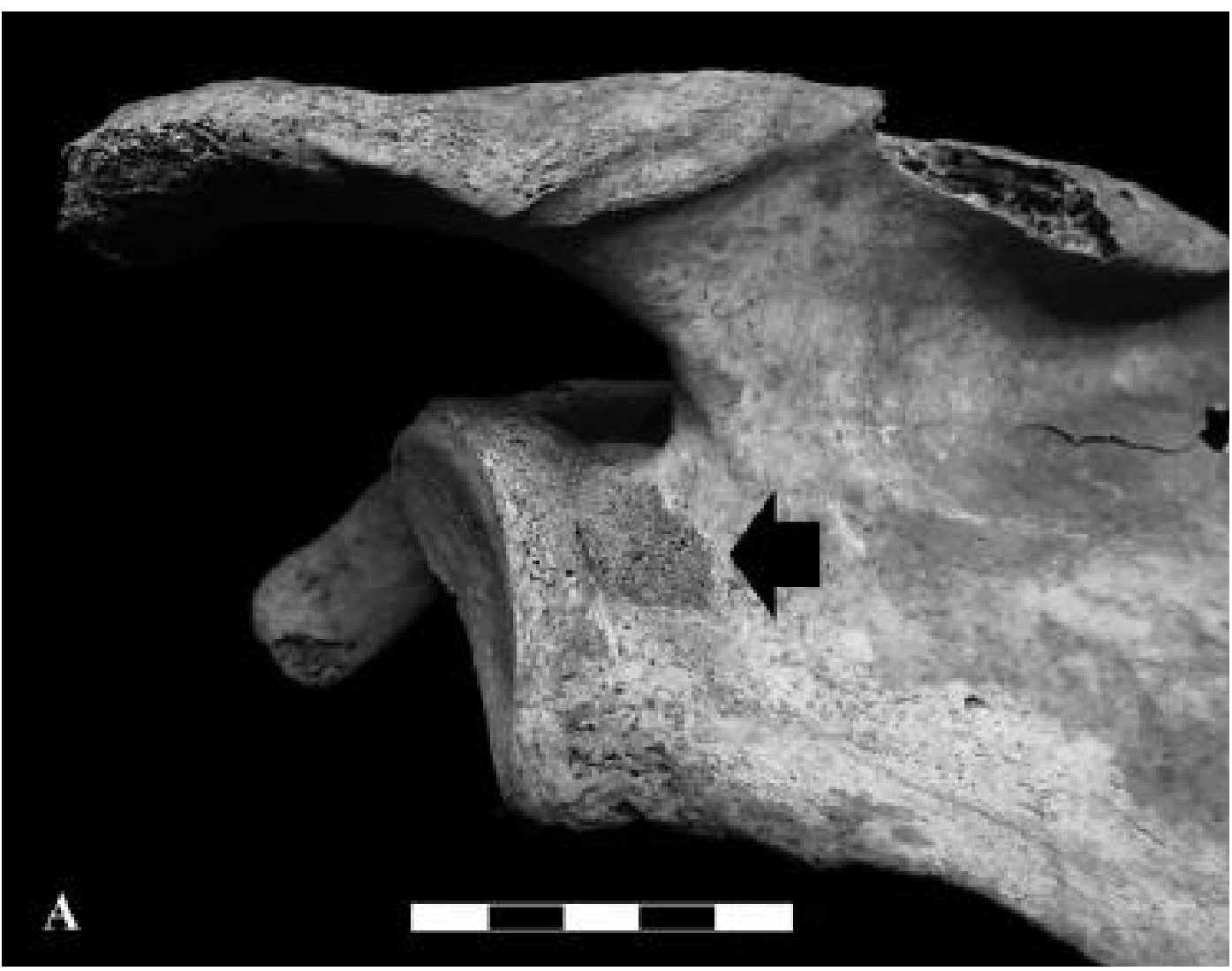

Figure 4a. 


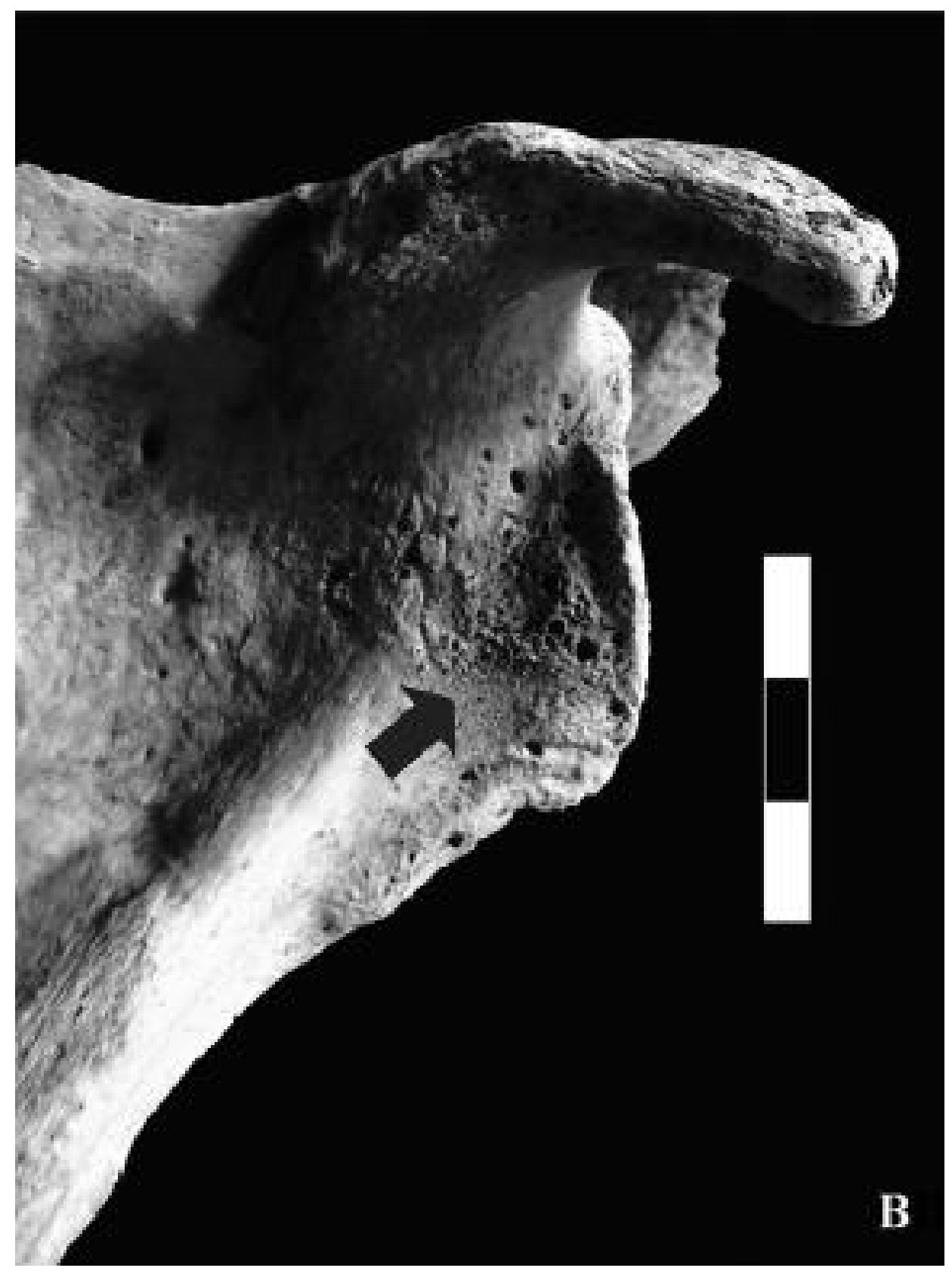

Figure $4 b$. 


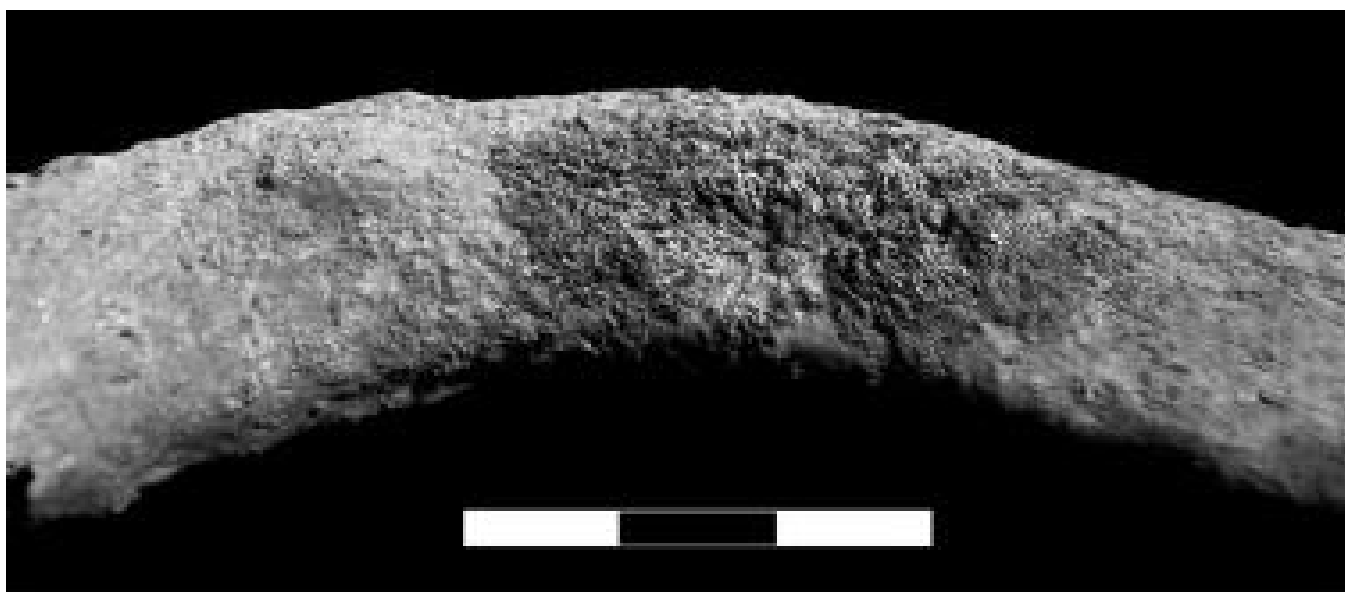

Figure 5.

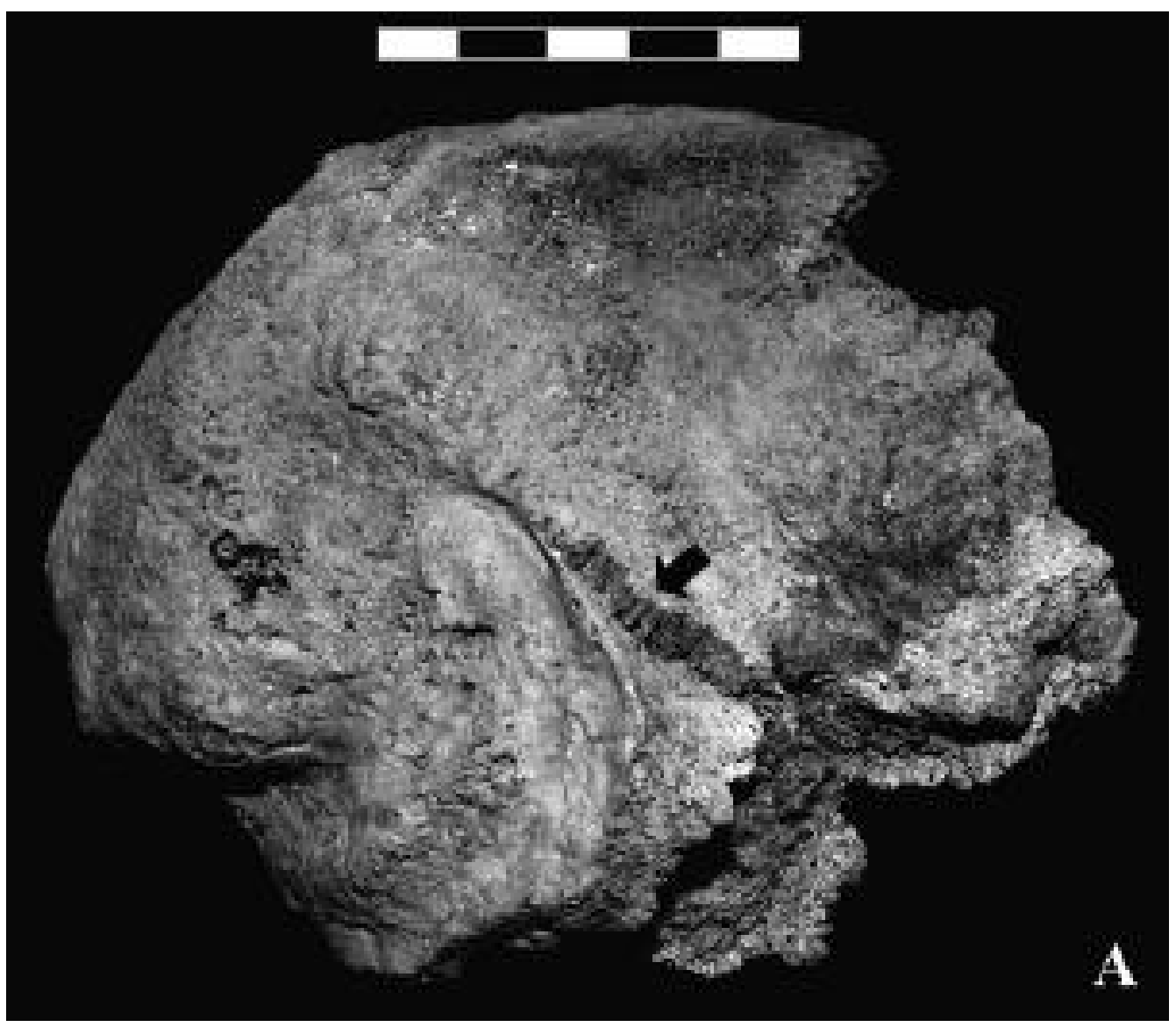

Figure 6a. 


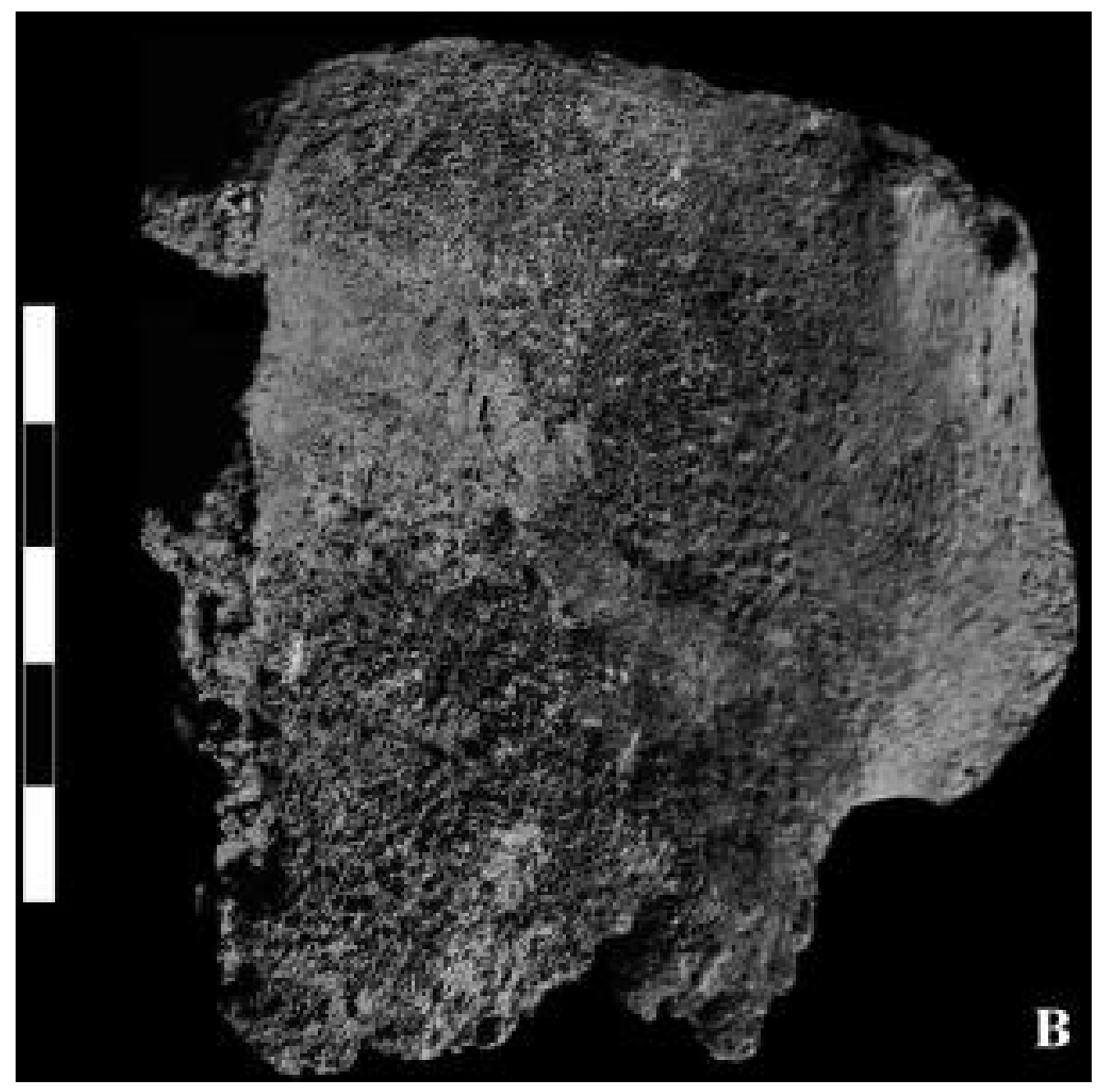

Figure $6 b$. 


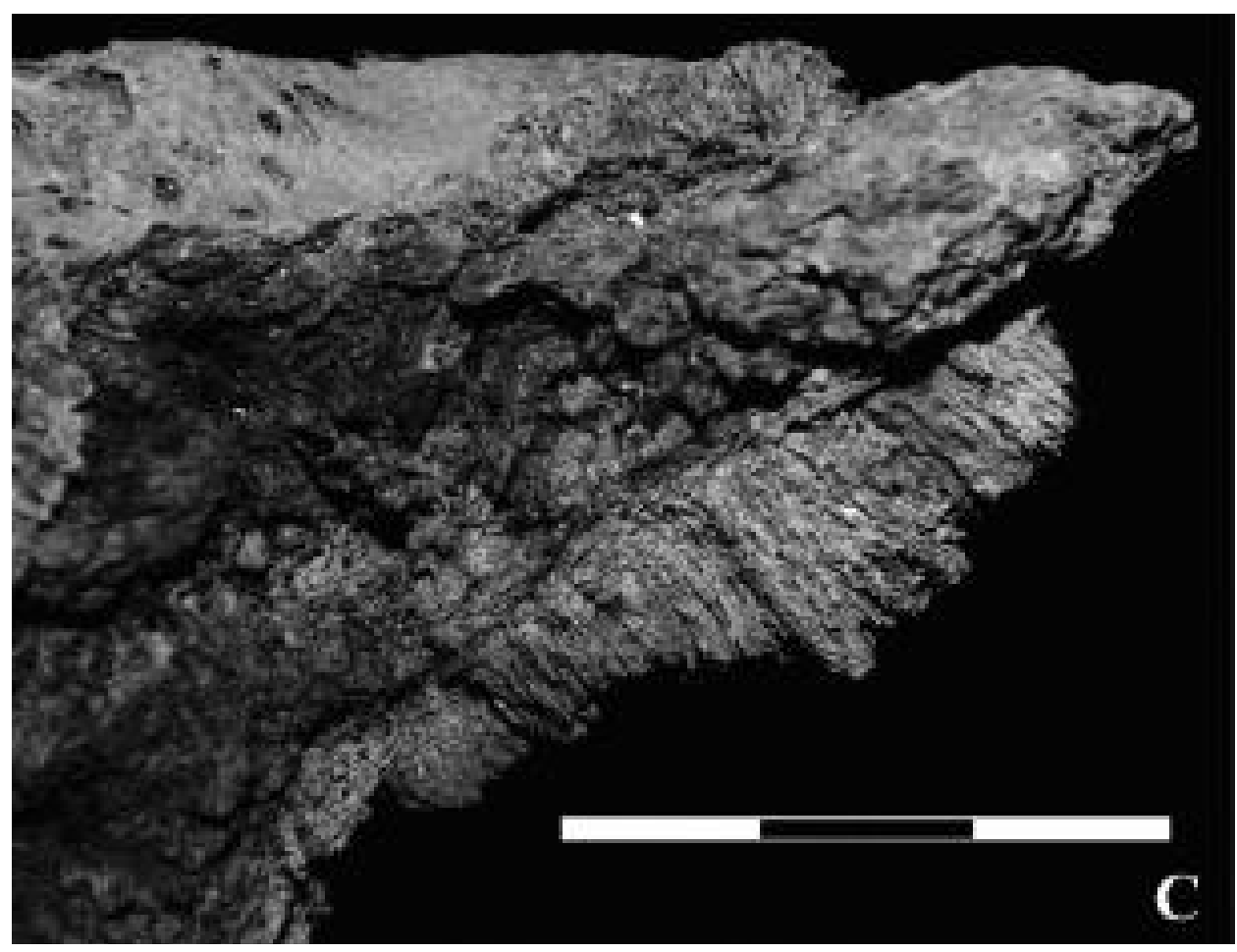

Figure 6c.

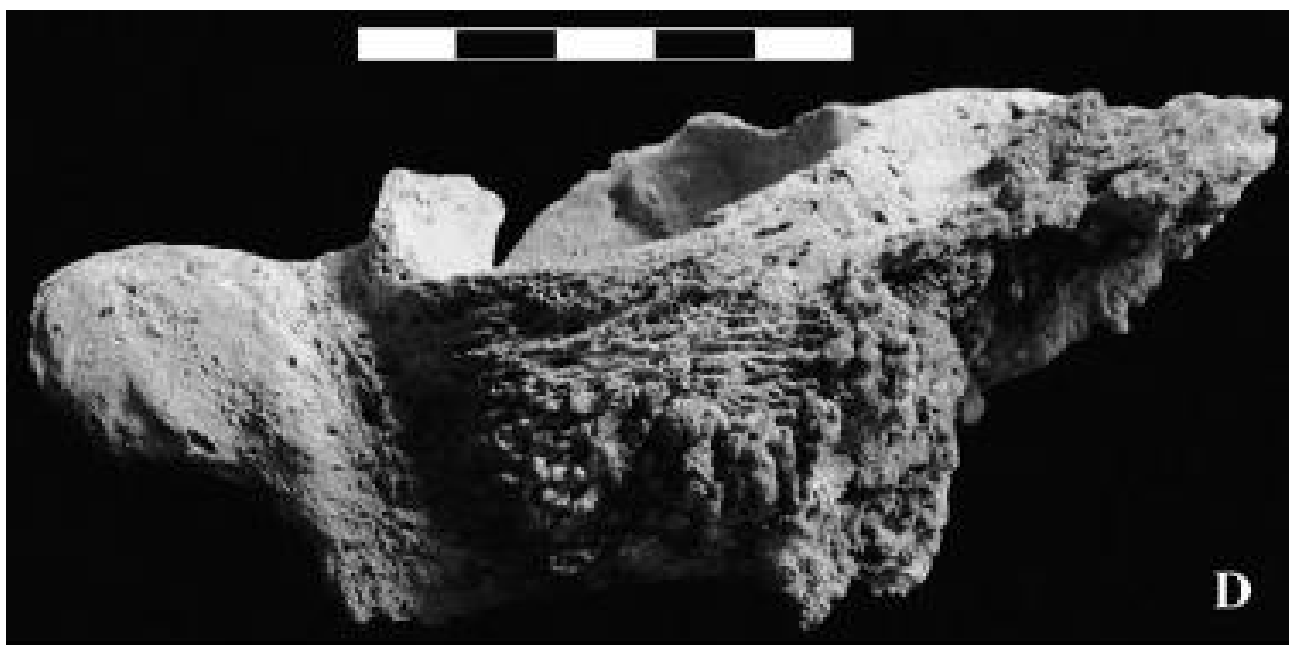




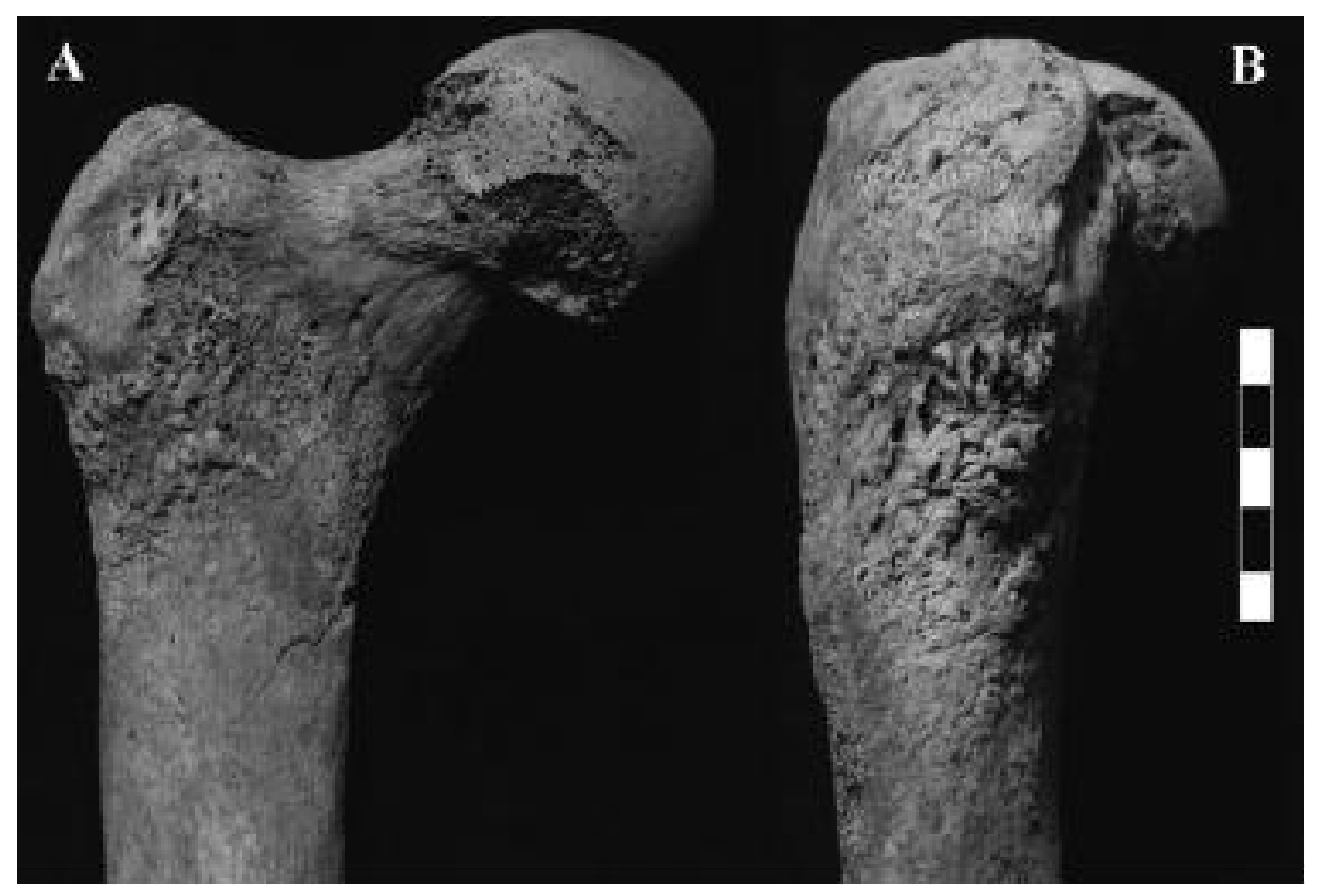

Figure 7.

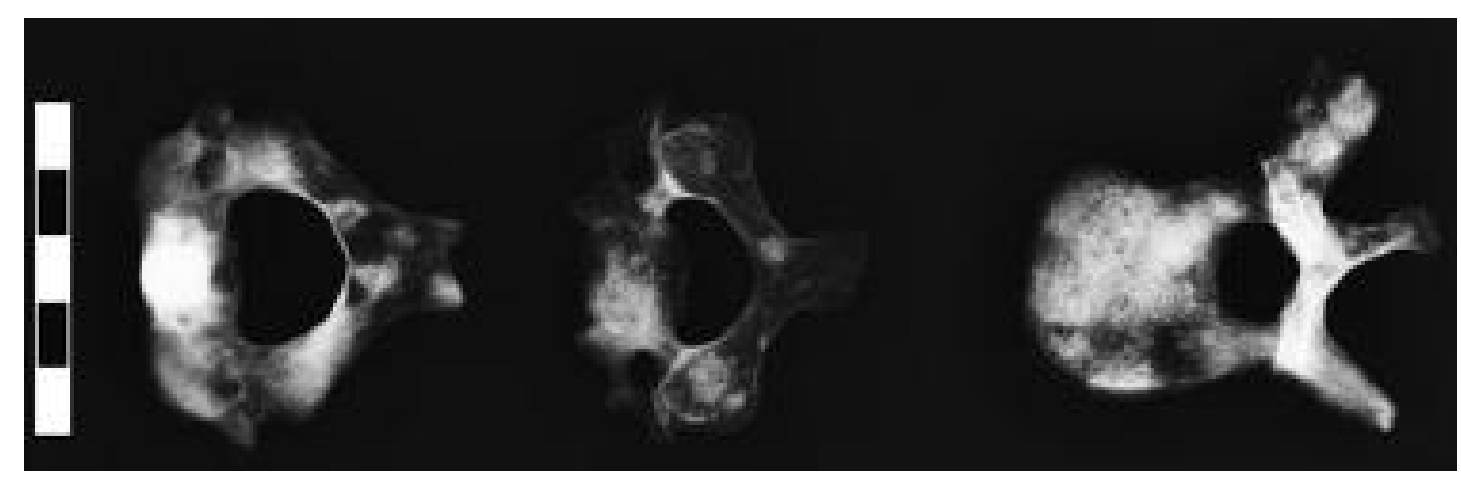

Figure 8. 


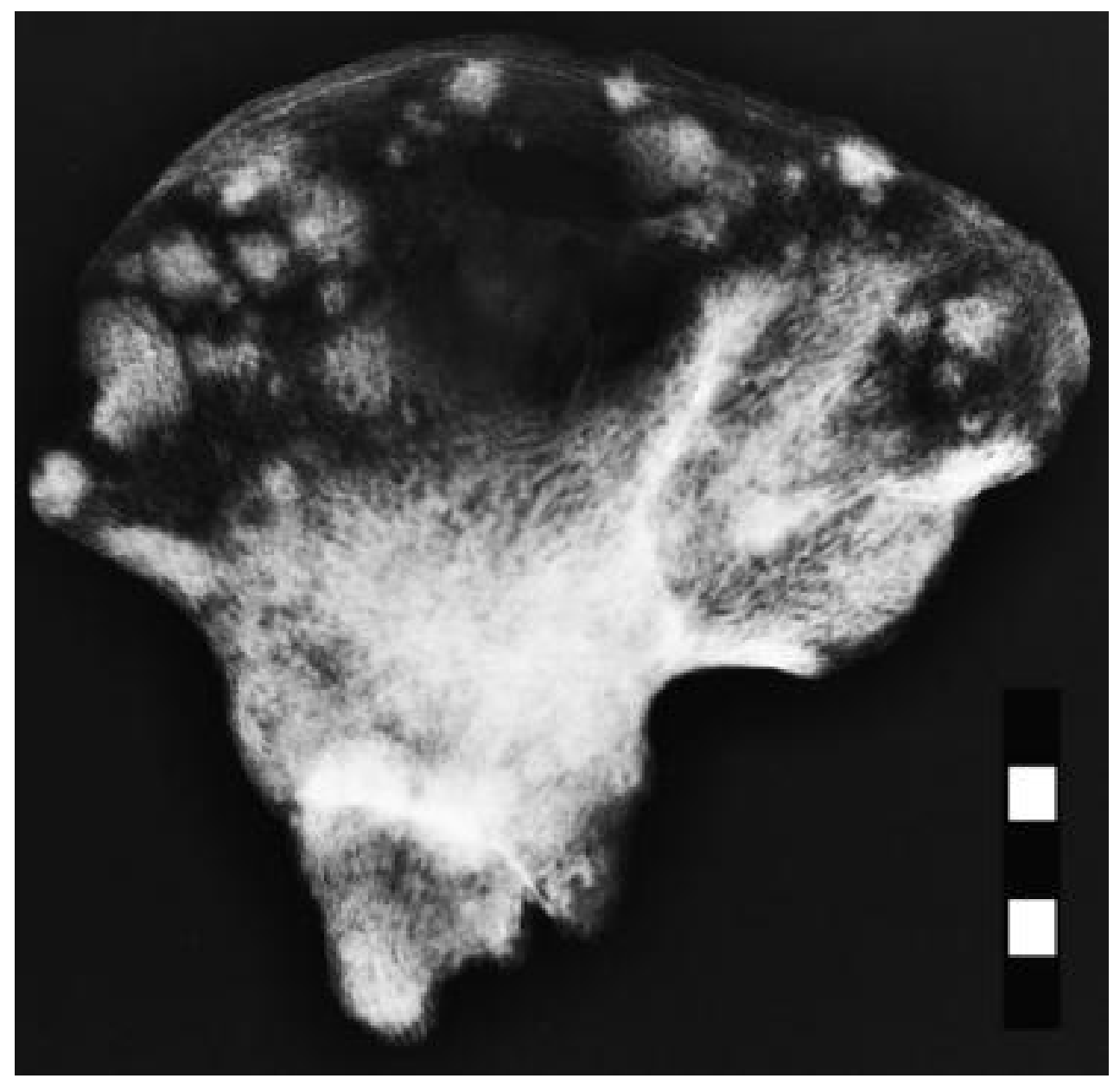

Figure 9. 


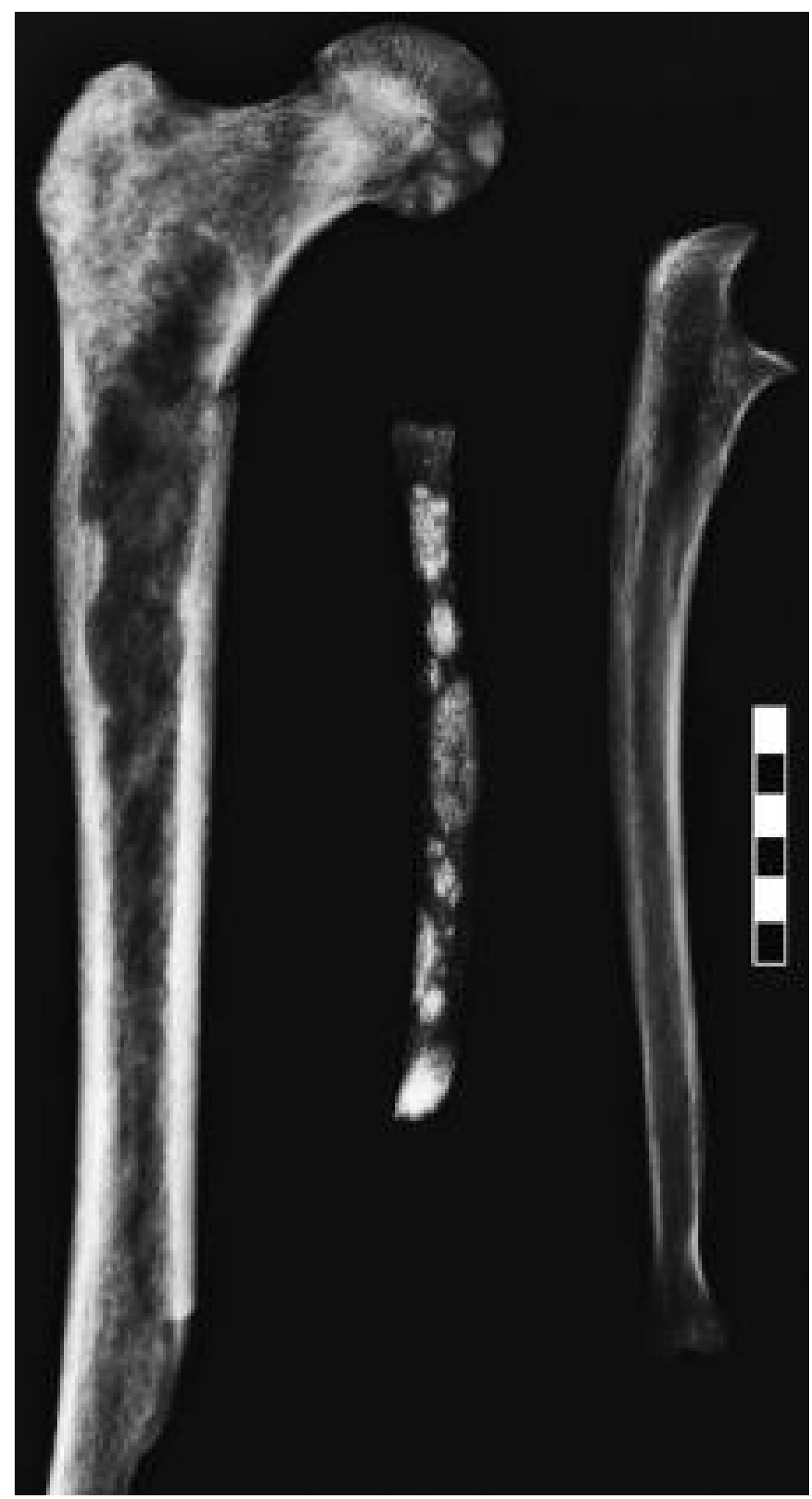

Figure 10. 